\title{
TWO NEW SPECIES OF PASSIFLORA (PASSIFLORACEAE) FROM SOUTH AMERICA
}

\author{
Linda K. Escobar \\ Departamento de Biología, Universidad de Antioquia, \\ Apartado Aéreo 1226, Medellín, Colombia \\ Present address: Plant Resources Center, Department of \\ Botany, University of Texas, Austin, TX 78713 USA.
}

\begin{abstract}
Recent botanical explorations have uncovered two new species of Passiflora, here described as P. fernandezii and P. viridescens. The first is placed in subgenus Passiflora, series Laurifolia, where it most closely resembles Passiflora riparia, the second in subgenus Plectostemma, section Decaloba, near Passiflora chelidonea.

KEY WORDS: Passiflora, systematics, South America.
\end{abstract}

Passiflora fernandezii L. Escobar, sp. nov. TYPE: BOLIVIA. Pando: Nicolas Suarez: entre Porvenir y Cachuelita, a lo largo de la pista, 19 Jan 1983, J. Fernández-Casas \& A. Susanna 3341 (holotype NY; isotype MO).

Passiflora (subgenus Passiflora series Laurifolia) ripariae Masters similis, sed pubescentia et forma hypanthii differt.

Liana. Plants pubescent, with straight, transparent trichomes ca $0.5 \mathrm{~mm}$ long. Stems angulate, striate, gray-green, sparingly pubescent. Leaf blades oblong, (3.5-) 5.0-9.4 cm long, (1.4-) $2.5-4.2 \mathrm{~cm}$ wide, obtuse then abruptly acuminate at apex, rounded at base, entire at margins, coriaceous, lustrous, gray-green, glabrous except for a few scattered trichomes at base on abaxial surface; petioles 1.2-1.8 cm long, with 2 paired, dark brown cup shaped nectaries ca $1 \mathrm{~mm}$ diam at mid-poiont on adaxial surface; stipules linear, ca 1 $\mathrm{cm}$ long, ca $0.5 \mathrm{~cm}$ wide. Peduncles single, $2.1-3.0 \mathrm{~cm}$ long; bracts 3 , verticillate, ovate. $1.9-2.4 \mathrm{~cm}$ long, $1.0-1.4 \mathrm{~cm}$ wide, acute to rounded at apex, cuneate at base, irregularly crenate at margins, with 4-6 dark brown nectaries scattered along margins above mid-point, densely pubescent; flower stipe ca 2 $\mathrm{mm}$ long. Flowers campanulate, ca $6 \mathrm{~cm}$ diam, pendant, white; hypanthium funnelform, $1.6-2.0 \mathrm{~cm}$ long, $2.4-2.9 \mathrm{~cm}$ wide at apex, $1.0-1.3 \mathrm{~cm}$ wide at base, 
with irregular rows of filaments $0.5-2.0 \mathrm{~mm}$ long in lower $1 / 2$ of inner surface; sepals ovate, $2.6-3.1 \mathrm{~cm}$ long, $1.5-2.1 \mathrm{~cm}$ wide, rounded at apex, softly coriaceous, with subapical corniculus ca $2 \mathrm{~mm}$ long on abaxial surface; petals oblong, ca $1.4 \mathrm{~cm}$ long, ca $0.7 \mathrm{~cm}$ wide, rounded at apex, narrowed at base, delicately membranaceous; corona in 2 series, filamentous, the outer filaments ca $6 \mathrm{~mm}$ long, ca $0.4 \mathrm{~mm}$ wide, the inner ones $2.3-2.5 \mathrm{~cm}$ long, ca $1.0 \mathrm{~mm}$ wide, banded with purple; operculum horizontal, nonplicate, membranaceous; ovary ellipsoidal, densely pubescent. Fruit unknown.

Distribution. This species is known only from the type collection in lowland Bolivia.

Passiflora fernandezii most closely resembles $P$. riparia Masters of subgenus Passiflora series Laurifolia (Killip 1938), but differs from it by the pubescence and shape of the hypanthium. Both of these characters are variable in collections ascribed to that species; the type, however, is described as glabrous (Masters 1872), and the illustration in Flora Brasiliensis depicts a cylindrical rather than funnelform hypanthium, so that further study of the Passiflora riparia complex is needed.

Passiflora viridescens L. Escobar, sp. nov. TYPE: PERÚ. Amazonas: Prov Chachapoyas: $22 \mathrm{~km}$ from Leimebamba on road to Balsas, ca 3000 m, 6 $6^{\circ} 45^{\prime} \mathrm{S}, 77^{\circ} 48^{\prime} \mathrm{W}, 4 \mathrm{Feb} 1985$, B. Stein \& C C. Todzia 2083 (holotype $\mathrm{MO})$.

Passiflora (subgenus Plectostemma section Decaloba) chelidoneae Masters similis morphologia foliarum, sed floribus multo majoribus sine operculo plicato et corona ligulata irregulari differt.

Herbaceous vine. Plants glabrous with angulate, striate stems. Leaf blades lanceolate, $12.0-12.8 \mathrm{~cm}$ long, $5.0-5.4 \mathrm{~cm}$ wide, 3 lobed at apex, with erect, triangular lateral lobes ca $1 \mathrm{~mm}$ long and mid-lobe ca $1 \mathrm{~cm}$ long, truncate to rounded at base, entire at margins, coriaceous; laminar nectaries ocellate, 10 13 , located between major veins on abaxial surface; petioles $1.2-1.3 \mathrm{~cm}$ long; stipules falcate, $5-6 \mathrm{~mm}$ long, ca $1 \mathrm{~mm}$ wide. Peduncles paired, ca $4.5 \mathrm{~cm}$ long; bracts 3 , dissitate, setaceous, 3-5 $\mathrm{mm}$ long, ca $0.5 \mathrm{~mm}$ wide. Flowers campanulate, ca $11 \mathrm{~cm}$ diam, probably pendant, greenish; hypanthium patelliform, ca $2 \mathrm{~mm}$ long, sepals narrowly triangular, $5.5 \mathrm{~cm}$ long, $1.1 \mathrm{~cm}$ wide at base, membranaceous; petals linear oblong, ca $2.8 \mathrm{~cm}$ long, $4-7 \mathrm{~mm}$ wide, membranaceous; corona in 1 irregular series, ligulate, with ligules ca 1.2-1.6 $\mathrm{mm}$ long; operculum spreading, lacerate to base, ca $0.7 \mathrm{~mm}$ long, membranaceous; ovary ellipsoidal, densely pubescent, with straight tan trichomes ca 0.1 mm long. Fruits unknown.

Distribution. This species is known only from the type collection in the Ceja de Montaña vegetation of Amazonas Department in northern Perú.

This new species is placed in subgenus Plectostemma, section Decaloba with species which Killip (1938), grouped in series "Punctatae." In leaf morphology, Passiflora viridescens resembles $P$. chelidonea, of the western slopes of the 
Andes in southern Colombia and northern Ecuador. It differs from that species by the larger flowers with a reduced ligulate corona and nonplicate operculum.

\section{LITERATURE CITED}

Killip, E.P. 1938. The American species of Passifloraceae. Pub. Field Mus. Nat. Hist. Bot. Ser. 19:1-613.

Masters, M.T. 1872. Passifloraceae. in Martius, Flora Brasiliensis, 13(1):599, pl 116. 


\section{$2 \mathrm{BHL}$ Biodiversity Heritage Library}

Escobar, Linda Katherine. 1989. "Two new species of Passiflora (Passifloraceae) from South America." Phytologia 66, 80-82. https://doi.org/10.5962/bhl.part.9803.

View This Item Online: https://www.biodiversitylibrary.org/item/47408

DOI: https://doi.org/10.5962/bhl.part.9803

Permalink: https://www.biodiversitylibrary.org/partpdf/9803

\section{Holding Institution}

New York Botanical Garden, LuEsther T. Mertz Library

\section{Sponsored by}

The LuEsther T Mertz Library, the New York Botanical Garden

\section{Copyright \& Reuse}

Copyright Status: In copyright. Digitized with the permission of the rights holder.

Rights Holder: Phytologia

License: http://creativecommons.org/licenses/by-nc-sa/3.0/

Rights: https://biodiversitylibrary.org/permissions

This document was created from content at the Biodiversity Heritage Library, the world's largest open access digital library for biodiversity literature and archives. Visit BHL at https://www.biodiversitylibrary.org. 